Original Article

\title{
ACTTRA SWD BAIT FORMULATION AGAINST DROSOPHILA SUZUKII AND ITS COMPATIBILITY WITH BERRY POLLINATION BY THE HONEY BEE, APIS MELLIFERA
}

\author{
Ricardo Alberto Toledo-Hernández ${ }^{1,2}$ \\ Mónica Pulido-Enríquez ${ }^{2}$ \\ Francisco Landeros-Pedro \\ Douglas Rodríguez ${ }^{2}$ \\ Daniel Sánchez ${ }^{1^{*}}$ \\ ${ }^{1}$ El Colegio de la Frontera Sur - Unidad Tapachula, Mexico \\ ${ }^{2}$ Applied Research, Driscolls Inc., Mexico \\ *corresponding author: dsanchez@ecosur.mx \\ Received: 15 March 2021; accepted: 06 August 2021
}

Abstract

Crop protection substances are continuously developed to prevent the decimation of non-target insect populations through insecticide use. The bait formulation Acttra SWD was created to attract the adult spotted-wing drosophila, a generalist pest of berries, and when mixed with insecticide would cause a reduction in the volume of insecticide applied, thus avoiding a complete coverage of crops and resulting in economic and ecological benefits to society. However, Acttra SWD has some compounds, including sugars and fruit odors, that might attract non-target fauna, especially insect pollinators. Therefore this study aimed (1) to investigate if Acttra SWD mixed with the recommended pesticide, i.e. spinosad (Entrust), is attractive to the honey bee, which is extensively used for berry pollination and (2) to evaluate the insecticidal activity of Acttra/Entrust in oral and contact tests on the same species. In all replicates, most foragers rejected feeders that offered Acttra/Entrust, and some switched to Acttra/Entrust-free feeders. Accordingly, mortality caused by this mixture in oral tests was low and did not differ from control, since the majority of bees did not consume the Acttra/Entrust treatment. However, mortality caused by this mixture was higher than in control groups in topical tests. Our results indicate that honey bees will not be attracted to and poisoned by crops sprayed with Acttra/Entrust, but contact with the bait would result in lethal or sub-lethal effects.

Keywords: Apidae, Attract and Kill, pesticide, safety, semiochemical

\section{INTRODUCTION}

Good production practices minimize their impact on natural ecosystems and maximize sustainability (Tilman et al., 2002). Consumers are aware of this, so they are changing their habits and acquiring commodities that are produced through sustainable agricultural practices (Vermeir \& Verbeke, 2006). However, a growing human population and modern lifestyle create demand for an ever-increasing volume and variety of agricultural goods. Modern intensive agricultural technology holds the promise to fulfill current and future humanity needs, even though it commonly involves the use of conventional chemical insecticides. Entire crops are sprayed to manage insect pests that reduce crop yield (Tilman et al., 2002), and though the use of insecticides reduces the damage caused by pests, the practice usually comes with deleterious side effects on non-target organisms, especially beneficial insects such as predators, parasitoids and pollinators (Carvalho, 2006). The honey bee, Apis mellifera L. is widely used to pollinate flowering crops around the world providing growers with economic inputs both from increased crop production and honey but is increasingly affected by the indiscriminate use 


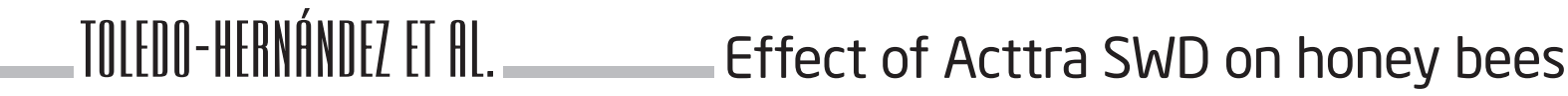

of insecticides (Gallai et al., 2009).

Biological control, i.e. the use of organisms or their metabolites for the control of pests, is currently considered a better, more environmentally friendly alternative to conventional synthetic insecticides (Heimpel \& Mills, 2017). Spinosyns, a group of molecules that is produced through the fermentation of the actinomicete Saccharopolyspora spinosa, are a prime example of microbial metabolites used as bioinsecticides (Thompson et al., 2000). They irreversibly bind to nicotinic acetylcholine receptors, causing continuous excitation of neurons in the central nervous system, paralysis and death of the insect (Salgado, 1998). Nicotinic acetylcholine receptors are present in all insects, and because of that spinosyns are regarded as highly toxic to many non-target terrestrial arthropods (Mayes et al., 2003; Millar \& Denholm, 2007; Biondi et al., 2012), and special formulations have been developed to increase their specificity to the pest (Perrin, 2000; Burns et al., 2001; Lockwood et al., 2001; Cloonan et al., 2019; Lasa et al., 2019). In the case of fruit flies (Diptera, Tephritidae) this is primarily achieved through a mixture of food bait, which attracts and phagostimulates the target species, and the killing agent, which can be a bioinsecticide or a drowning solution (El-Sayed et al., 2009). In the design of the "attract and kill"formulation, some components might also work to repel non-target species (Mangan \& Moreno, 2009).

Because the "attract and kill" formulation lures the pest to the application points, it is unnecessary for the crop to be completely covered with the insecticide, and instead the formulation is applied either as large drops, bursts on the base of trees or placed inside bait stations (Gazit et al., 2013). Non-targets are not attracted to the bait, and the probability of contact between non-target insects and the insecticide formulation dramatically decreases. Therefore, the use of "attract and kill" formulations should be significantly more compatible with the management of honey bee colonies for crop pollination than conventional cover sprays of chemical pesticides for crop protection (Kirkland, 1999; CabreraMarín et al., 2016). GF-120 (Dow Agrosciences,
(A) is a formulation that consists of $\mathrm{NH}_{3}$-releasing compounds, sugars and the bioinsecticide spinosad (a mixture of spinosyns $A$ and $D$ ), aimed to control fruit flies in Mexico (Sánchez et al., 2012). Even though spinosad is considered to be a minor threat to wildlife including mammals, it has been shown to be toxic in contact and oral tests to pollinators such as the honey bee (Miles, 2003; Hardstone \& Scott, 2010). However, given that the GF-120 formulation has shown to be mostly repellent to bee pollinators (Mangan \& Moreno, 2009; Gómez-Escobar et al., 2014), actual oral toxicity to pollinators is substantially reduced. More importantly, application at an ultra low volume (ULV, 2 liters of diluted formulation per ha) with large size droplet completely eliminates the necessity of complete crop coverage, leaving most of the crop free of insecticides, which might provide refuge for pollinators (Cabrera-Marín et al., 2016).

The Spotted-Wing Drosophila, Drosophila suzuki (Matsumura) (SWD) (Diptera: Drosophilidae) is a serious pest of soft fruit and berries (e.g. various Rubus and Vaccinium species) (Asplen et al., 2015). Its populations are reduced through the application of spinosad or spinetoram (a mixture of spinosyns J and $L$ )-based insecticides in the form of ULV micron-sized droplets over the foliage of crops (Beers et al., 2011; Bruck et al., 2011; Van Timmeren \& Isaacs, 2013). Such a mode of application implies that the spinosyns enter in contact with non-target species as well, especially if applied when bees are foraging.

A new product, Acttra SWD (ISCA Technologies Inc., Riverside, CA, US), aimed for the management of $D$. suzukii, incorporates into a ready-to-use flowable slow release formulation a proprietary semiochemical blend that provides specificity of attraction. It also contains a blend of phagostimulant compounds, including sugars, that induces the consumption of the bait by the attracted target pest (Klick et al., 2019). When mixed with the bioinsecticide spinosad, it can be applied as a short burst in the lower part of blackberry or raspberry plants, away from inflorescences and fruits, thus reducing the contact with potential pollinators such as bees. However, it was hypothesized that the 
entire blend, or some compounds, in Acttra SWD attracts honey bees, so even though contact through spraying is considerably reduced, residual contact and potential ingestion by honey bees cannot be discarded. Thus here we report the results of evaluating the attraction of Acttra SWD mixed with spinosad to honey bee foragers following Cabrera-Marín et al. (2015) procedures. We aimed to determine whether honey bee foragers are able to reject Acttra + spinosad treated food sources when alternative Acttra + spinosad-free resources are available, as a strategy to make agriculture and pollination more compatible. We also conducted two other experiments to determine honey bee mortality by contact to, and by ingestion of, Acttra SWD mixed with spinosad.

\section{MATERIAL AND METHODS}

\section{Study site}

The experimental work was carried out at a raspberry (Rubus idaeus L.; Rosales: Rosaceae) plantation of 32 ha, in the locality Romero de Torres in the municipality of Zamora, Michoacán,

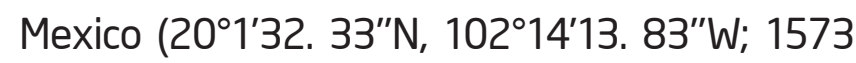
m.a.s.l.) during the flowering and fruiting season in mid-March to mid-July 2017. The climate is sub-humid with rains in summer, an annual temperature of $16-22^{\circ} \mathrm{C}$, and annual rainfall of 700-1000 mm (INEGl, 2009). The surrounding vegetation is mainly composed of pine trees (Pinales: Pinaceae), Alysumm L. flowers (Brassicales: Brassicaceae) and corn plants (Zea mays L.; Poales: Poaceae), which are not subjected to any plant protection scheme involving agrochemicals. Management practices within the raspberry plantation consist of mowing weeds and the application of such botanical extracts as Aranova (extract of garlic, neem and cinnamon, Zare Agrhos S. de R.L. de C.V.), Aza-direct 1.2 CE $^{\circ}$ (Azadiractin, Gowan mexicana S.A.P.I. de C.V.), Killwalc (Pyrethrins of Chrysanthemum; BioCampo, S.A. de C.V.), microbial insecticides (entomopathogenic fungi) and fungicides (Elevat ${ }^{\circ}$ A.I. Fenhexamid; Switch 62.5 WG A.I. Ciprodinil and Fludioxonil) (Supplementary Material).

\section{Chemicals}

ActtraSWD' $[$ A.I. sugars (invertose 33.1\%, sucrose
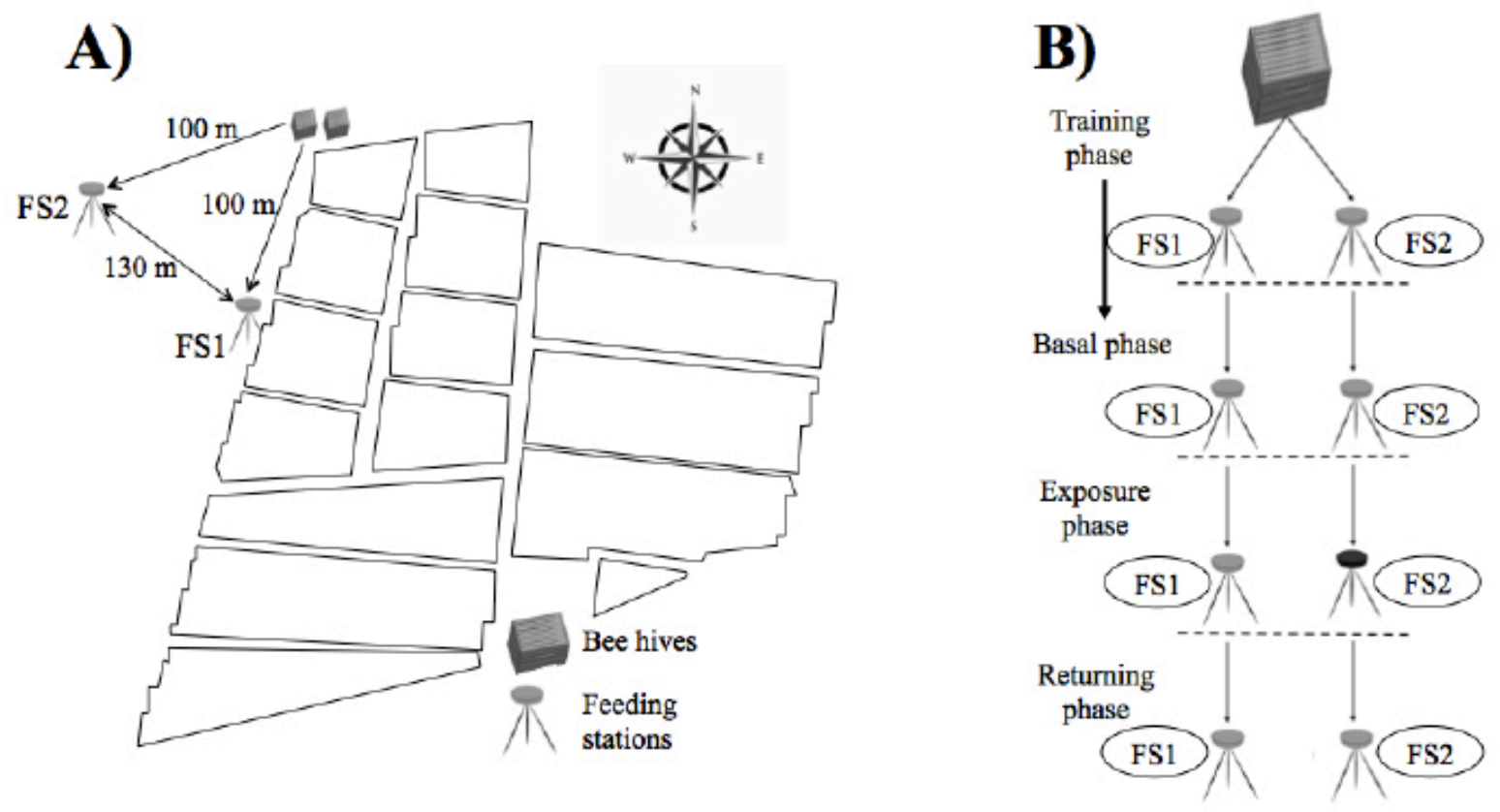

Fig. 1. (A) Location of experimental honey bee colonies and feeding stations (FS1 and FS2) in the plantation. (B) Experimental setup of experiment 1. Training phase, foragers are trained to collect sucrose from both feeders (grey circles). Basal phase, foragers visiting each feeder were counted. Exposure phase, the FS2 was removed and a new one containing Acttra/Entrust was offered (black circle). Returning phase consisted of putting back sucrose solution in FS2. Each phase, except training, lasted 20 min. 


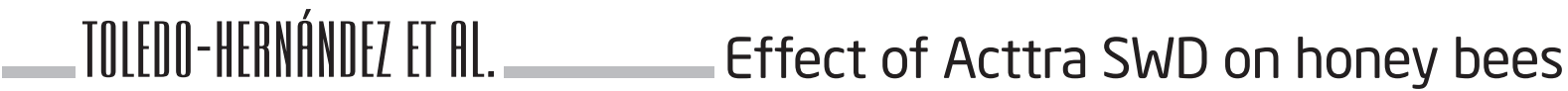

3.0\%), methionol $0.6 \%$ and spray adjuvants $63.1 \%$, ISCA Technologies Inc., USA] is a feeding stimulant adjuvant registered as a commercial formulation for the SWD in USA. The pesticide Entrust ${ }^{\circ}$ (A.I. spinosad 22.14\%, Dow Agro-Sciences, Mexico S.A. de C.V.) was chosen as the source of spinosad because of their frequent use by berry farmers in Mexico. We added Entrust to Acttra SWD (from now on Acttra/Entrust) to obtain a final concentration of 110.7 ppm of spinosad, as used for the control of the SWD. Because Exalt is commonly used against SWD, it was included in the experiment (A.I. spinetoram 5.87\%, Dow Agro-Sciences, Mexico S.A. de C.V.) in order to evaluate its impact on bees. Spinetoram is a mixture of spinosyns $]$ and $L$ and shares many features with spinosad (Schutze et al., 2018). Exalt was diluted with water to a final concentration of 29.35 ppm of spinetoram according to directions provided by the manufacturer for SWD control.

\section{Biological material}

Two honey bee colonies from a local apiary were used in the experiments. Both colonies were considered in good health by an experienced local beekeeper who visually inspected brood, food reserves, number of adults, and for the presence of parasites and disease. The colonies were located on the edge of the raspberry plantation to minimize disturbance by routine work in the farm (Fig. 1A). Experiments were carried out between 08:00 and 15:00, since at this time honey bees were commonly visiting floral resources and it was possible to train them to feeding stations.

\section{Experiment 1 - Do honey bees reject Acttra/Entrust-treated food sources?}

In this experiment we wanted to know if foragers would abandon a rich food source polluted with the Acttra/Entrust mixture, and if these foragers would move to nearby pesticide-free resources exploited by nestmates. Following the methodology of Cabrera-Marín et al. (2015), we trained five to ten foragers from one colony to collect a $2.0 \mathrm{M}$ sucrose solution from a feeding station (FS1, a circular plastic plate containing $100 \mathrm{ml}$ of sucrose solution atop a camera tripod), located $100 \mathrm{~m}$ away the colony. Next, a second group of foragers was trained to a different feeding station (FS2) located $130 \mathrm{~m}$ from the FS1, but at $100 \mathrm{~m}$ from the colony as shown in Fig. 1A. We differentiated trained foragers visiting the two feeders by painting them on the thorax with water-based paints of different colors. Newcomer foragers were painted with another set of colors (blue paint for FS1 foragers and red paint for FS2 foragers) to distinguish the feeder they were visiting and from the trained foragers (Sánchez et al., 2009). Observers were positioned at each feeder, so that any forager painted with a color not corresponding to the feeder they were visiting was trapped with a suction tube and maintained inside a plastic jar with sucrose solution until the end of the experiment. We carried out the previous procedure in order to maintain a stable and faithful set of foragers for each feeder. Since there were honey bee colonies other than ours in the surroundings, we marked the foragers from our colonies at the entrance with a painting device as carried out by Mikery-Pacheco et al. (2013). Over the paint marks deposited by this device, a different dot was painted as pointed out lines above to know the feeder station they were trained to.

Once we observed that 50-100 foragers were consistently visiting each feeder, and that no foragers were switching between feeders, we initiated the basal phase and registered the color of the foragers in each feeder at every minute during 20 min. Next, we initiated the exposure phase: the feeder of the FS2 was removed and a new one containing Acttra/Entrust was shown for 20 min; again we registered the number and the color of the foragers visiting each feeder as in the previous phase. Finally, the returning phase consisted of putting back a sucrose solution in FS2 and counting again the number of bees foraging at each feeder for another 20 min (Fig. 1B). We expected the foragers at FS2 to stop visiting this feeder during the exposure phase, and perhaps to start switching to FS1, which was still offering sucrose solution only. Overall we obtained ten replicates per colony. To 
avoid pseudoreplication, we trapped previously marked foragers with suction tubes during each new replicate and release them at the end of each replicate.

\section{Experiment 2 - Oral susceptibility laboratory conditions}

Groups of 8-10 foragers, which were collected from feeding stations with the use of suction tubes, were transferred into plastic jars (24.5 $\mathrm{cm}$ height $\times 13.5 \mathrm{~cm}$ diameter) covered with a nylon cap. In the laboratory, ten groups were exposed to each of the following treatments: (a) control 1 [honey/water solution $50 \%$ with $10 \mathrm{ml}$ of vegetable food dye per liter of solution (Rojo 122; McCormick Company Inc., Spain)]; (b) control 2 (10 $\mathrm{ml}$ of vegetable food dye per liter of water); (c) Acttra/Entrust at 110 ppm spinosad (added with $10 \mathrm{ml}$ of vegetable food dye per liter of solution), and (d) Acttra/Entrust/Honey (Acttra/Entrust mixed in equal proportion with honey at 110 ppm spinosad, added with $10 \mathrm{ml}$ of vegetable food dye per liter of solution). Exposure consisted of placing twenty $50 \mathrm{ml}$ drops of each treatment on a $5 \mathrm{~cm} \times 5 \mathrm{~cm}$ strip of Parafilm ${ }^{\oplus}$ (Heathrow Scientific, Vernon Hills, IL, USA) inside each container for $30 \mathrm{~min}$. The dye was used to determine if the bees consumed the drops as described by Silva et al. (2013) for Anastrepha fraterculus (Wiedemann) (Diptera: Tephritidae). Thus, any living or dead bee with its abdomen colored red consumed the treatment (Fig. 2). After exposure, bees were fed $2.0 \mathrm{M}$ sucrose solution and maintained at $30 \pm 5^{\circ} \mathrm{C}$, $50 \pm 5 \% \mathrm{RH}$ in complete darkness as suggested by Williams et al. (2013). We considered each group an experimental replicate. We recorded mortality at $24 \mathrm{~h}$ after exposure; a bee was considered dead if it did not respond to a slight touch with a paintbrush.

\section{Experiment 3 - Application of Acttra/Entrust on foragers in field conditions}

Bee foragers were trained to FS2 between 09:00 and 11:00 $h$ as described above. However, in this case the plate consisted of a $1 \mathrm{~m}^{2}$ square piece of Styrofoam. When approximately 100 foragers were observed feeding, the treatments were applied at the recommended dose to control $D$. suzukii in Mexico (ANEBERRIES, 2019) with a backpack sprayer [STIHL ${ }^{\oplus}$, model 51 at $\left.60 \mathrm{PSI}\left(5.62 \mathrm{~kg} / \mathrm{cm}^{2}\right)\right]$ with brass nozzles (model number TP8002E, Teejet Technologies, Wheaton, IL), ensuring that all bees were covered with spray droplets. The treatments were: 1) Exalt, final concentration of spinetoram of 29.35 ppm in water; 2) Entrust, final concentration of spinosad of $110 \mathrm{ppm}$ in water; 3) Acttra/Entrust, final concentration of spinosad of 110 ppm in Acttra SWD and, 4) water only as the control treatment. To avoid carry over of the different substances in the different treatments, the backpack sprayer was thoroughly cleaned externally and internally with liquid dishwashing detergent (Axion, Colgate-Palmolive Company, Mexico) in water at $5 \mathrm{~g} / \mathrm{L}$ and rinsed profusely with tap water so that no pesticide residue remained. The piece of Styrofoam was discarded after each replicate. Each treatment was replicated five times with approximately 100 bees per replicate. After exposure we trapped all foragers by placing a

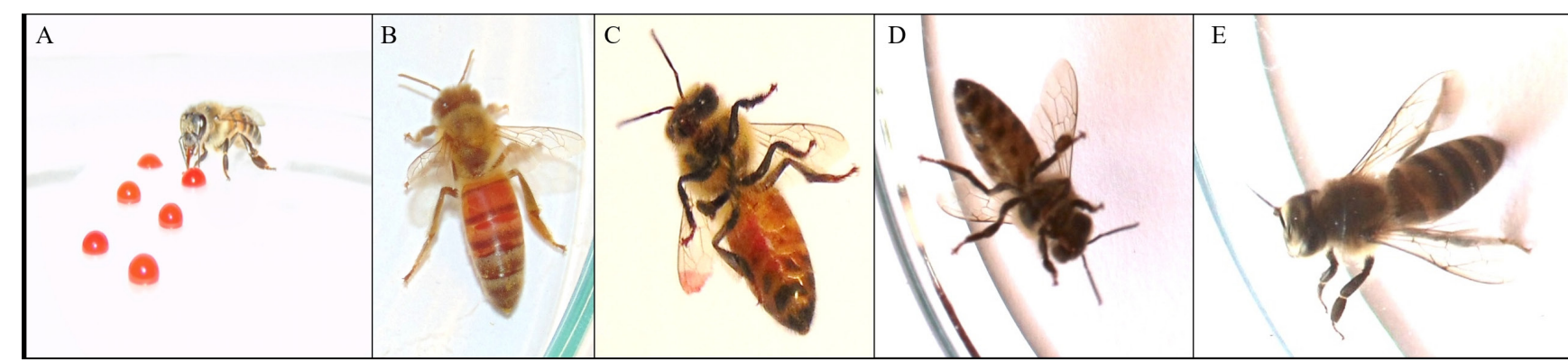

Fig. 2. Apis mellifera exposed to drops of each treatment $(A)$ and foragers with their abdomen colored red after feeding on the treatment containing natural colorant (B and $C$ ); foragers that did not consume colored food are also shown ( $D$ and $E$ ). 
plastic container on the feeding station; gentle knocks on the feeder stimulated the foragers to fly upwards and to remain on the walls of the container, which was then closed with a screw cap. The container had $1 \mathrm{~mm}$ diameter holes to allow gas exchange; foragers were supplied freshly prepared 2.0 M sucrose solution and maintained in laboratory at $30 \pm 5^{\circ} \mathrm{C}, 50 \pm 5 \% \mathrm{RH}$ in complete darkness. Mortality was recorded at $24 \mathrm{~h}$ after exposure as mentioned before.

\section{Data analysis}

For experiment 1 we summed up the number of foragers observed in each phase resulting in three time-correlated data points per replicate and per feeding station. We analyzed these data following a Linear Mixed Model approach with the package Ime4 v 1.1 (Bates et al., 2015), in which a replicate was considered a random variable and colony, treatment and phase as fixed variables. Percent mortality from experiment 2 and experiment 3 was analyzed with the use of the ANOVA approach. Statistics were run in $R$ environment v4.0.3 (R Development Core Team, 2020) under Mac OS High Sierra v 10.13.6.

\section{RESULTS}

\section{Experiment 1 - Do honey bees reject Acttra/ Entrust-treated food sources?}

Data from both colonies followed similar patterns at $a=0.01 \quad(t=-2.36 ; d f=37 ; p=0.02)$, so we pooled the data. The mean number of foragers ( \pm standard error) visiting the FS2 during the exposure phase, when the formulation was offered, was extremely low $(8.65 \pm 1.00)$, compared to the basal phase $(385.65 \pm 27.80)$ and to the returning phase (227.05 \pm 23.08$)$. This resulted in a significant difference between the basal and the exposure phases $(t=5.69, d f=78$, $p<0.001)$ and the exposure and the returning phases ( $t=3.91, d f=78, p<0.001)$. On the other hand, the mean number of foragers visiting the FS1 during basal phase (396.60 \pm 36.37$)$, exposure phase $(453.7 \pm 38.94)$ and returning phase (455.05 \pm 36.50$)$ remained high. The mean number of foragers in the basal and the returning phases was not significantly different $(t=-1.78, d f=78, p=0.08)$.

Interestingly enough, we observed many foragers switching from FS2 to FS1 during the exposure phase. We found significant differences $(t<-3.40, d f=218, p<0.001)$ in the mean number of foragers between the exposure phase $(16.2 \pm 2.07)$ and the basal phase (6.18 \pm 2.31$)$ and returning phase (7.12 \pm 1.12$)$. No significant difference was found between basal and returning phases $(t=0.367, d f=218, p=0.72)$.

\section{Experiment 2 - Oral susceptibility in laboratory conditions}

One group from the Acttra-Entrust treatment was removed because half the bees escaped from the container during manipulation. All bees from the control 1 treatment had their abdomen colored red, while some had it red in

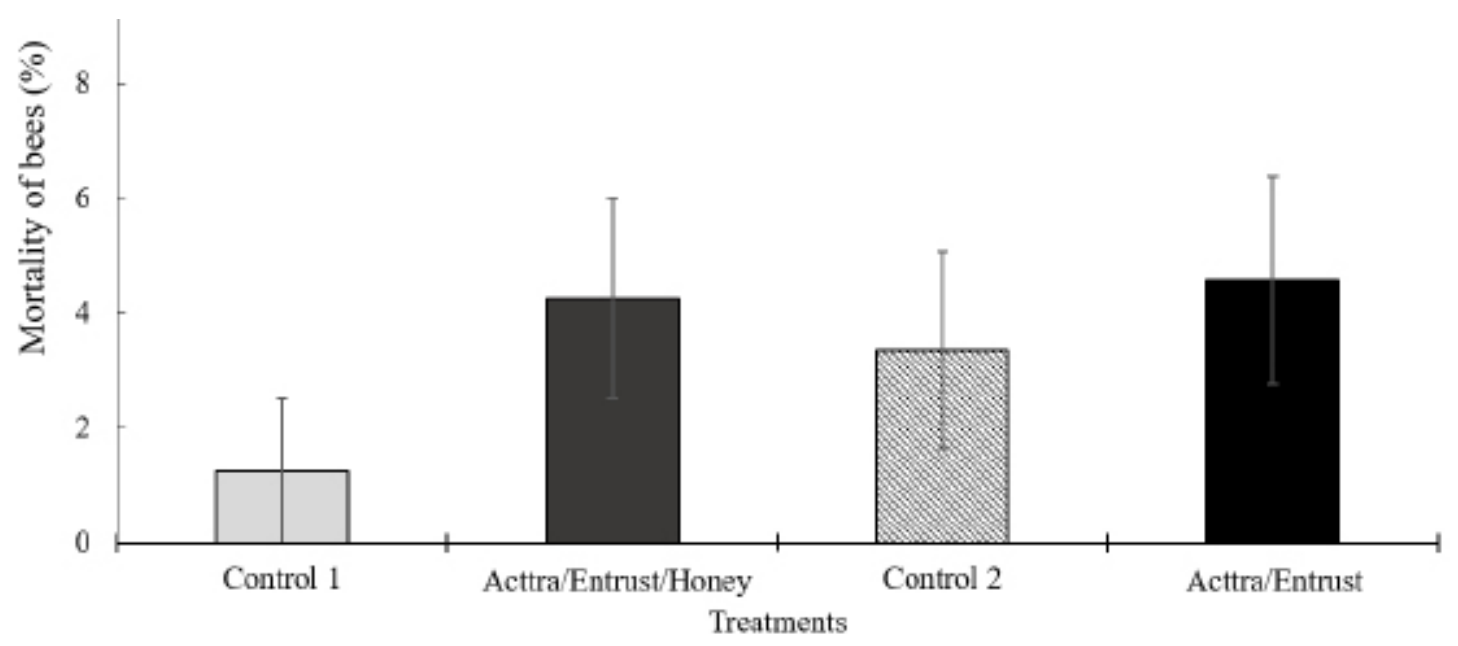

Fig. 3. Mean mortality ( \pm standard error) of foragers exposed to each treatment in experiment 2 (see text for further details). Treatments were not significantly different at $a=0.05$. 


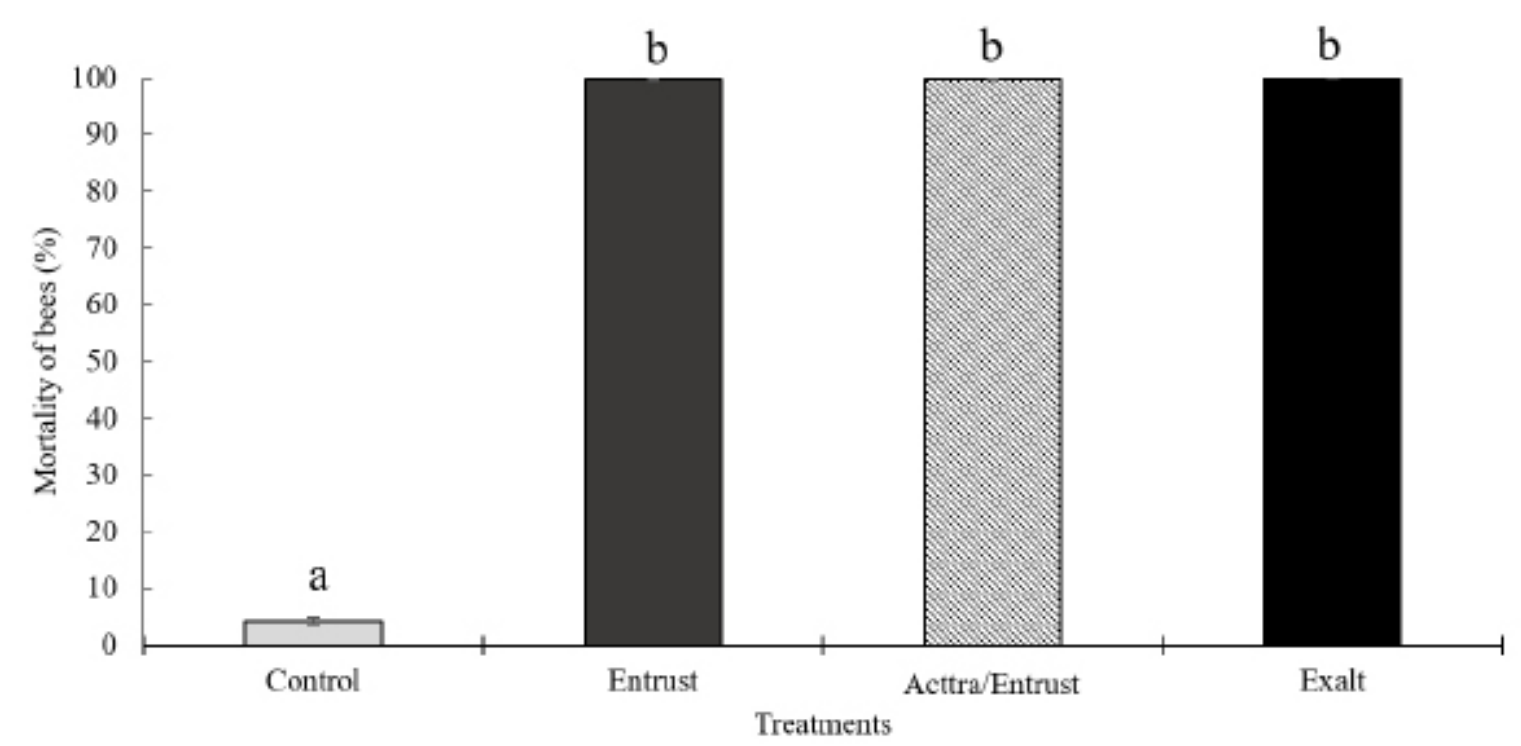

Fig. 4. Mean mortality ( \pm standard error) of honey bee foragers in experiment 3 (see text for further details). The same letter indicates no significant difference (Tukey's HSD test, $a=0.05$ ).

control 2. As expected, no bee from the Acttra/ Entrust and Acttra/Entrust/Honey treatments had their abdomen colored red and even rejected it if mixed with honey. Mortality among the four treatments was low and not significantly different $(F=0.83, \mathrm{df}=3,35, \mathrm{p}=0.48)$, even though a slightly higher mortality was observed in the Acttra/Entrust treatment (Fig. 3).

\section{Experiment 3 - Application of Acttra/Entrust on foragers in field conditions}

The results of this experiment showed that toxicity by contact is high. All treatments, except for control, showed mortalities of or close to $100 \%$ (Fig. 4; F=3645, df=3, 16, $p<0.001$ ).

\section{DISCUSSION}

This study revealed three important aspects about the use of Acttra SWD/Entrust in the field. First, we showed that the formulation repelled bees since most of the foragers moved from the Acttra/Entrust feeder to the feeder without it, and moreover the remaining foragers that continued visiting the Acttra/Entrust feeder did not collect it. Our data suggest that Acttra SWD was clearly discouraging foragers from collecting it, since the number of foragers in the Acttra/Entrust feeder was reduced by over
95\% during the exposure phase. The GF-120 formulation elicited a similar behavior in honey bees and stingless bees (Gómez-Escobar et al., 2014; Mangan \& Moreno, 2009). In this case, the protein contents in this formulation are assumed to keep bees from consuming it, despite the sugar in it. Honey bees should be able to taste in Acttra SWD invertose, sucrose, methionol and the inerts. We hypothesize that methionol discouraged our bees from collecting the formulation upon contact, since all foragers landed on the platform, but did not collect it and instead were repelled from a distance. Because this formulation constitutes proprietary technology, the composition of the vehicle is unknown to us and could also be a source of repellence, but this has to be tested. Many foragers that abandoned the Acttra/Entrust feeder during the exposure phase showed up at the sucrose feeder, which suggests that, as long as there are food alternatives available, some bees will prefer to move to these resources.

A similar result was obtained by Cabrera-Marín et al. (2015) with honey bees exposed to GF-120, when foragers abandoned the feeder that changed from offering sucrose to show the pesticide. Thus, some spaces must be left in the field untreated, for example through the application of the formulation at evenly spaced 


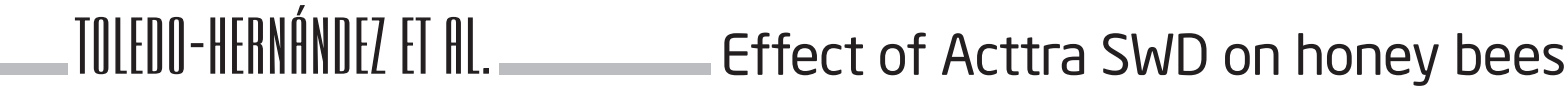

locations and that the application does not cause too much aerosolization in order to reach floral structures. In any case, our bees landed on the platform, and some had to make contact with the formulation to reject it, and some foragers still tried to collect it. Further evaluations need to be conducted in order to determine the presence of residues of spinosad in honey from honey bee colonies located nearby treated farms and to estimate actual risks.

Secondly, the low toxicity observed in Experiment 2 is in agreement with the lack of attraction of honey bees towards Acttra/ Entrust observed in Experiment 1. No foragers exposed to droplets with Acttra SWD had their abdomens colored red, and they preferred to starve than to feed upon any of the Acttra treatments, which can be considered a no-choice test. This result gives further evidence on the safety of Acttra/Entrust to honey bees. However, during application it would be necessary to provide food for the bee colonies, since they could stop foraging completely and become weaker if no other food source were available. Although it is likely that a mixture Acttra/Exalt should also be repellent to honey bees, further studies must be done to confirm this.

The third important finding of our study is that the acute toxicity of spray applications aimed to completely cover the plantation with Acttra/ Entrust can be as high as that observed for Entrust and Exalt formulations at the recommended field dose. Given that several studies have shown spinosyns to be highly toxic to $A$. mellifera, even similar to neonicotinoids, in oral and topical tests (Gómez-Escobar et al., 2018; Miles, 2003; Padilha et al., 2020; Stanley et al., 2015), it was not surprising to observe such high mortality when honeybees were experimentally covered by each spinosad treatment by directly aiming the spray on them. This, nonetheless, would be the worst-case scenario. However, the recommended application mode of Acttra/Entrust in the field can be considered safe for bees because 1) a splash of $1 \mathrm{~m}$-long of product is left on the lower cover, far from the fructification structures (Klick et al., 2019) and,
2) the formulation is repellent to bees. When Acttra is not used, the application of Entrust or Exalt is carried out in such a way that the plantation is completely covered with a layer of the insecticide. This mode of application leaves no chance for bees to escape contact, particularly if it is done during periods of high foraging activity (Cabrera-Marín et al., 2016). However, if it is done during nighttime or very early in the morning, the risk to bees is greatly reduced, as shown in laboratory, semifield and field tests for spinosad (Miles et al., 2012; Schoonover \& Larson, 1995). Residual deleterious effects on honeybees need to be addressed as well, since tarsal contact with dry, or even wet residues, will occur.

The environmental fate and half-life of spinosad and spinetoram is similar. They rapidly break-down on plant surfaces exposed to sunlight (2-16 d), water and soil (<1 d), but it takes longer in attenuated light conditions (9-17 d) and even longer in anaerobic conditions in water (161-250 d). It is strongly adsorbed by soil particles, so the probability of leaching is low (Cleveland, 2007). Thus, even though other routes of exposure do not seem to represent a threat, more research is needed, to discard any potential chronic intoxication by Acttra/ Entrust, or that its effects (at field realistic concentrations) are not detrimental in the long term.

In conclusion, in this work we found that if Acttra/Entrust, which is formulated under the principle to "attract and kill" the pest (Klick et al., 2019), is applied according to manufacturer's instructions the probability of causing acute toxicity to honey bees is very low, making it compatible with commercial pollination in the conditions of the study site.

\section{ACKNOWLEDGMENTS}

We thank Luis García (Driscoll's Grower) for allowing us to use their fields for this study. Arturo Sánchez and Rafael Zarate provided valuable help with fieldwork. We greatly appreciate the Acttra SWD ${ }^{\oplus}$ provided by Jimmy 
Klick, Michael Seagraves (Driscoll's, Inc., Watsonville, CA), and ISCA Technologies Inc. (Riverside, CA). We appreciate the helpful comments made by Dr. Agenor Mafra-Neto on the manuscript.

\section{REFERENCES}

ANEBERRIES. (2019). Asociación Nacional de Exportadores de Berries. Lista de plaguicidas autorizados para uso en berries 2018. http:// www.aneberries.mx/lista-de-plaguicidasautorizados-2017.

Asplen, M. K., Anfora, G., Biondi, A., Choi, D.-S., Chu, D., Daane, K. M., ... Hutchison, W. D. (2015). Invasion biology of spotted wing Drosophila (Drosophila suzuki): a global perspective and future priorities. Journal of Pest Science, 88(3), 469-494. DOl: 10.1007/s10340-015-0681-z

Bates, D., Maechler, M., Bolker, B., Walker, S. (2015). Fitting linear mixed-effects models using Ime4. Journal of Statistical Software, 67, 1-48.

Beers, E. H., Van Steenwyk, R. A., Shearer, P. W., Coates, W. W., Grant, J. A. (2011). Developing Drosophila suzukii management programs for sweet cherry in the western United States. Pest Management Science, 6711), 1386-1395. D0l: 10.1002/ps.2279

Biondi, A., Mommaerts, V., Smagghe, G., Viñuela, E., Zappalà, L., Desneux, N. (2012). The non-target impact of spinosyns on beneficial arthropods. Pest Management Science, 68, 1523-1536. DOI: 10.1002/ ps.3396

Bruck, D. J., Bolda, M., Tanigoshi, L., Klick, J., Kleiber, J., Defrancesco, J., .... Spitler, H. (2011). Laboratory and field comparisons of insecticides to reduce infestation of Drosophila suzukii in berry crops. Pest Management Science, 6711), 1375-1385. DOl: 10.1002/ps.2242

Burns, R. E., Harris, D. L., Moreno, D. S., Eger, J. E. (2001). Efficacy of Spinosad bait sprays to control Mediterranean and Caribbean fruit flies (Diptera: Tephritidae) in commercial citrus in Florida. The Florida Entomologist, 84, 672-678. DOl: 10.2307/3496400
Cabrera-Marín, N. V., Liedo, P., Sánchez, D. (2016). The effect of application rate of GF-120 (Spinosad) and malathion on the mortality of Apis mellifera (Hymenoptera: Apidae) foragers. Journal of Economic Entomology, 109(2), 515-519. DOl: 10.1093/jee/ tov385

Cabrera-Marín, N. V., Liedo, P., Vandame, R., SánchezGuillén, D. (2015). Foraging allocation in the honey bee, Apis mellifera L. (Hymenoptera, Apidae), tuned by the presence of the Spinosad-based pesticide GF-120. Neotropical Entomology, 44, 166-172. DOl: 10.1007/s13744-014-0262-5

Carvalho, F. P. (2006). Agriculture, pesticides, food security and food safety. Environmental Science \& Policy, 9, 685-692. DOl: 10.1016/j. envsci.2006.08.002

Cleveland, C. B. (2007). Environmental and health assessments for Spinosad against the backdrop of organic certification: Acs Publications.

Cloonan, K. R., Hernández-Cumplido, J., De Sousa, A. L. V., Ramalho, D. G., Burrack, H. J., Della Rosa, L., ... Gut, L. J. (2019). Laboratory and field evaluation of hostrelated foraging odor-cue combinations to attract Drosophila suzukii (Diptera: Drosophilidae). Journal of Economic Entomology, 172(6), 2850-2860. DOl: 10.1093/jee/toz224

El-Sayed, A. M., Suckling, D. M., Byers, J. A., Jang, E. B., Wearing, C. H. (2009). Potential of "lure and kill" in long-term pest management and eradication of invasive species. Journal of Economic Entomology, 102(3), 815-835. DOl: 10.1603/029.102.0301

Gallai, N., Salles, J.-M., Settele, J., Vaissière, B. E. (2009). Economic valuation of the vulnerability of world agriculture confronted with pollinator decline. Ecological Economics, 68(3), 810-821. DOl: 10.1016/j. ecolecon.2008.06.014

Gazit, Y., Gavriel, S., Akiva, R., Timar, D. (2013). Toxicity of baited Spinosad formulations to Ceratitis capitata. from the laboratory to the application. Entomologia Experimentalis et Applicata, 1472), 120-125. DOl: 
10.1111/eea.12051

Gómez-Escobar, E., Liedo, P." Montoya, P., MéndezVillarreal, A., Guzmán, M., Vandame, R., Sánchez, D. (2018). Effect of GF-120 (Spinosad) aerial sprays on colonies of the stingless bee Scaptotrigona mexicana (Hymenoptera: Apidae) and the honey bee (Hymenoptera: Apidae). Journal of Economic Entomology, 177(4), 1711-1715. DOl: 10.1093/jee/ toy 152

Gómez-Escobar, E., Liedo, P., Montoya, P." Vandame, R., Sánchez, D. (2014). Behavioral response of two species of stingless bees and the honey bee (Hymenoptera, Apidae) to GF-120. Journal of Economic Entomology, 107, 1447-1449. DOl: 10.1603/EC13490

Hardstone, M. C., \& Scott, J. G. (2010). Is Apis mellifera more sensitive to insecticides than other insects? Pest Management Science, 66(11), 1171-1180. DOl: 10.1002/ps.2001

Heimpel, G. E., \& Mills, N. J. (2017). Biological control. Cambridge University Press.

INEGI. (2009). Instituto Nacional de Estadística y Geografía. Síntesis de información geográfica del estado de Michoacán. from Instituto Nacional de Estadística y Geografía http://www.inegi.org.mx

Kirkland, R. (1999). Evaluation of Success 2SC on honey bees. Report 219-99 Dow AgroSciences, Indianapolis, IN.

Klick, J., Rodriguez-Saona, C. R., Cumplido, J. H., Holdcraft, R. J., Urrutia, W. H., da Silva, R. O., Seagraves, M. P. (2019). Testing a novel attract-and-kill strategy for Drosophila suzukii (Diptera: Drosophilidae) management. Journal of Insect Science, 19(1): 3; 1-6. DOl: 10.1093/jisesa/iey132

Lasa, R., Toledo-Hernández, R. A., Rodríguez, D., Williams, T. (2019). Raspberry as a source for the development of Drosophila suzukii attractants: laboratory and commercial polytunnel trials. Insects, 10(5), 137. DOl: 10.3390/insects10050137
Lockwood, J. A., Narisu, Schell, S. P., Lockwood, D. R. (2001). Canola oil as a kairomonal attractant of rangeland grasshoppers: an economical liquid bait for insecticide formulation. International Journal of Pest Management, 473), 185-194. DOl: 10.1080/09670870010018887

Mangan, R. L., \& Moreno, A. T. (2009). Honey bee foraging preferences, effects of sugars, and fruit fly toxic bait components. Journal of Economic Entomology, 102, 1472-1481. DOl: 10.1603/029.102.0411

Mayes, M. A., Thompson, G. D., Husband, B., Miles, M. M. (2003). Spinosad toxicity to pollinators and associated risk. Reviews of Environmental Contamination and Toxicology, 179, 37-71. DOl: 10.1007/0-387-21731-2_2

Mikery-Pacheco, O., Solórzano-Gordillo, E., SánchezGuillén, D. (2013). Método de marcaje masivo de abejas Apis mellifera (Hymenoptera: Apidae) para estudios ecoetológicos. Acta Zoológica Mexicana nS, 29, 248-251.

Miles, M. (2003). The effects of spinosad, a naturally derived insect control agent, to the honeybee. Bulletin of Insectology, 56, 611-624.

Miles, M., Alix, A., Bourgouin, C., Schmitzer, S. (2012). Effects of Spinosad on honey bees (Apis mellifera): findings from over ten years of testing and commercial use. Julius-Kühn-Archiv, 437, 107-114. DOl: 10.5073/jka.2012.437.032

Millar, N. S., \& Denholm, I. (2007). Nicotinic acetylcholine receptors: targets for commercially important insecticides. Invertebrate Neuroscience, 71), 53-66. DOl: 10.1007/s10158-006-0040-0

Padilha, A. C., Piovesan, B., Morais, M. C., de B. Pazini, J., Zotti, M. J., Botton, M., Grützmacher, A. D. (2020). Toxicity of insecticides on Neotropical stingless bees Plebeia emerina (Friese) and Tetragonisca fiebrigi (Schwarz) (Hymenoptera: Apidae: Meliponini). Ecotoxicology, 29(1), 119-128. DOl: 10.1007/s10646019-02150-x 


\section{ง. APPC. SCL. VOL. 65 IIV. 2 2021}

Perrin, B. (2000). Improving insecticides through encapsulation. Pesticide Outlook, 17(2), 68-71. DOl: 10.1039/B006324]

R Development Core Team. (2020). R: A language and environment for statistical computing (Version 4.0.3). Vienna, Austria. Retrieved from http://www.Rproject.org. Date of access: June 28th, 2021

Salgado, V. L. (1998). Studies on the mode of action of Spinosad: insect symptoms and physiological correlates. Pesticide Biochemistry and Physiology, 60(2), 91-102. DOI: 10.1006/pest.1998.2332

Sánchez, D., Nieh, J. C., León, A., Vandame, R. (2009). Food recruitment information can spatially redirect employed stingless bee foragers. Ethology, 715, 1175-1181. DOl: 10.1111/j.1439-0310.2009.01703.x

Sánchez, D., Solórzano-Gordillo, E., Liedo, P., Vandame, R. (2012). Effect of the natural pesticide Spinosad (GF-120 formulation) on the foraging behavior of Plebeia moureana (Hymenoptera: Apidae). Journal of Economic Entomology, 105, 1234-1237. DOl: 10.1603/EC12047

Schoonover, J. R., \& Larson, L. L. (1995). Laboratory activity of Spinosad on non-target beneficial arthropods, 1994. Arthropod Management Tests, 2011), 357-357. DOl: 10.1093/amt/20.1.357

Schutze, I. X., Baronio, C. A., Baldin, M. M., Loek, A. E., Botton, M. (2018). Toxicity and residual effects of toxic baits with spinosyns on the South American fruit fly. Pesquisa Agropecuária Brasileira, 53(2), 144151. DOl: 10.1590/50100-204X2018000200002

Silva, M. A., Bezerra-Silva, G. C. D., Vendramim, J. D., Mastrangelo, T., Forim, M. R. (2013). Neem derivatives are not effective as toxic bait for tephritid fruit flies. Journal of Economic Entomology, 106(4), 1772-1779. DOl: 10.1603/EC12071

Stanley, J., Sah, K., Jain, S. K., Bhatt, J. C., Sushil, S. N. (2015). Evaluation of pesticide toxicity at their field recommended doses to honeybees, Apis cerana and A. mellifera through laboratory, semi-field and field studies. Chemosphere, 179,668-674. DOl: 10.1016/j. chemosphere.2014.07.039

Thompson, G. D., Dutton, R., Sparks, T. C. (2000). Spinosad-a case study: an example from a natural products discovery programme. Pest Management Science, 56(8), 696-702. DOl: 10.1002/1526-4998(200008)56:8\%3C696::AIDPS182\%3E3.0.CO;2-5

Tilman, D., Cassman, K. G., Matson, P. A., Naylor, R., Polasky, S. (2002). Agricultural sustainability and intensive production practices. Nature, 418, 671677. DOl: 10.1038/nature01014

Van Timmeren, S., \& Isaacs, R. (2013). Control of spotted wing drosophila, Drosophila suzukili, by specific insecticides and by conventional and organic crop protection programs. Crop Protection, 54, 126133. DOl: 10.1016/j.cropro.2013.08.003

Vermeir, l., \& Verbeke, W. (2006). Sustainable food consumption: exploring the consumer "attitude behavioral intention" gap. Journal of Agricultural and Environmental Ethics, 192), 169-194. DOl: 10.1007/ s10806-005-5485-3

Williams, G. R., Alaux, C., Costa, C., Csaki, T., Doublet, V., Eisenhardt, D., ... Medrzycki, P. (2013). Standard methods for maintaining adult Apis mellifera in cages under in vitro laboratory conditions. Journal of Apicultural Research, 52(1), 1-36. DOl: 10.3896/ IBRA.1.52.1.04 


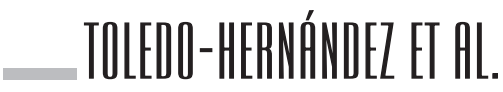

\section{Supplementary material}

List of products used during the study period in the raspberry plantation

\begin{tabular}{|c|c|c|c|c|}
\hline Active ingredient & Trade name & Manufacturer & Classification & Application dates \\
\hline $\begin{array}{l}\text { Nitrogen and } \\
\text { aminoacids }\end{array}$ & Algacell & $\begin{array}{c}\text { Agroplasma } \\
\text { Ferticell SA de CV }\end{array}$ & $\begin{array}{l}\text { Fertilizers and } \\
\text { amendment }\end{array}$ & 1 and 5 Feb \\
\hline Aminoacids & Amino Plant & $\begin{array}{l}\text { Organic Extract } \\
\text { Plant }\end{array}$ & Fertilizers & $\begin{array}{c}25 \text { Jan, } 1 \text { and } 26 \text { Feb, } \\
5 \text { March }\end{array}$ \\
\hline $\begin{array}{l}\text { Garlic, neem and } \\
\text { cinnamon }\end{array}$ & Aranova & Zare Agrhos & $\begin{array}{l}\text { Botanical extracts } \\
\text { used as insect } \\
\text { repellents }\end{array}$ & 26 Feb, 24 March \\
\hline Azadiracthin & Aza-direct 1.2 CE & $\begin{array}{l}\text { Gowan mexicana } \\
\text { S.A.P.I. DE CV }\end{array}$ & Insecticide & $\begin{array}{l}1 \text { Feb, } 15 \text { March, } \\
21 \text { Apr, } 4 \text { May }\end{array}$ \\
\hline Fenhexamid & Elevat & $\begin{array}{l}\text { Arysta Lifecience } \\
\text { México, S.A. DE C.V. }\end{array}$ & Fungicide & 25 Jan \\
\hline Seaweed Ecklonia & Kelp & $\begin{array}{c}\text { Algas y Bioderiva- } \\
\text { dos Marinos, S.A. } \\
\text { de C.V. }\end{array}$ & $\begin{array}{l}\text { Fertilizers and } \\
\text { amendment }\end{array}$ & 26 Jan \\
\hline $\begin{array}{l}\text { Chrysanthemum } \\
\text { extracts }\end{array}$ & Killwalc & $\begin{array}{c}\text { BioCampo, S.A. de } \\
\text { C.V. }\end{array}$ & $\begin{array}{l}\text { Botanical extracts } \\
\text { used as insect } \\
\text { repellents/ } \\
\text { pesticides }\end{array}$ & $\begin{array}{c}1 \text { and } 26 \text { Feb, } \\
5 \text { March, } 14 \mathrm{Apr}\end{array}$ \\
\hline $\begin{array}{l}\text { Nitrogen and } \\
\text { organic compounds }\end{array}$ & Maxigrow & Cosmoflor & Fertilizer & 1 Feb \\
\hline Azoxystrobin & Maxtrobyn & $\begin{array}{l}\text { Helm de México, } \\
\text { S.A. }\end{array}$ & Fungicide & 1 Feb \\
\hline $\begin{array}{l}\text { Conidia of Isaria } \\
\text { fumosorosea }\end{array}$ & PAE-SIN & $\begin{array}{l}\text { Agrobiologicos del } \\
\text { noreste S.A. DE C.V. }\end{array}$ & Biopesticide & 9 March, 2 May \\
\hline $\begin{array}{l}\text { Ciprodinil and fludi- } \\
\text { oxonil }\end{array}$ & Switch 62.5 WG & $\begin{array}{l}\text { Syngenta Agro, } \\
\text { S.A. DE C.V. }\end{array}$ & Fungicide & 18 Feb \\
\hline $\begin{array}{l}\text { Conidia of Hirrsu- } \\
\text { tella thompsonii }\end{array}$ & Thompzar & Zare Agrhos & Biopesticide & 26 Feb, 5 March, \\
\hline $\begin{array}{l}\text { Conidia of Verticil- } \\
\quad \text { lium lecanni }\end{array}$ & VERTI-SIN & $\begin{array}{l}\text { Agrobiologicos del } \\
\text { noreste S.A. DE C.V. }\end{array}$ & Biopesticide & 9 and 30 March \\
\hline Nitrogen & Wiserganic & WISErg Corporation & $\begin{array}{l}\text { Fertilizers and } \\
\text { amendment }\end{array}$ & $\begin{array}{c}1 \text { and } 26 \text { Feb, } \\
5 \text { March }\end{array}$ \\
\hline Siloxane & Xtender & $\begin{array}{c}\text { Fertilizantes e } \\
\text { Insumos Agrícolas } \\
\text { S.A. de C.V. }\end{array}$ & Adjuvant & 25 Jan, 18 Feb \\
\hline
\end{tabular}

